\title{
DEVELOPMENT OF HEALTH TOURISM IN WEST POMERANIAN VOIVODESHIP
}

\author{
Elżbieta Sieńko-Awierianów \\ University of Szczecin, Faculty of Health and Physical Education, Institute of Physical Culture Sciences, Poland \\ Address for correspondence: \\ Elżbieta Sieńko-Awierianów \\ Insitute of Physical Culture Sciences, University of Szczecin \\ Al. Piastów 40B, blok 6, 71-065 Szczecin, Poland \\ Email: elzbieta.sienko-awierianow@usz.edu.pl
}

\begin{abstract}
Ahstract Health resort treatment is an important element of the Polish health care system. An aging population, an increase in the amount of free time and income, as well as a healthy lifestyle trend are the main factors for the development of health tourism. West Pomeranian voivodeship ranks $3^{\text {rd }}$ in the country in terms of the number of health resorts, as well as is the undisputed leader in terms of the number of people visiting Polish resorts. In 2017, over $25 \%$ of patients underwent medical treatment in health resorts in West Pomeranian voivodeship. The aim of the study was to analyze the potential of health resorts in West Pomeranian voivodeship and to assess the development of tourist traffic in health resorts in recent years.

West Pomeranian voivodeship observes a steady increase in the number of health resort visitors using the services offered by health establishments and a changing structure of patients in regard to the financing method - there is a growing number of people who finance their stay in the health resort on their own. In order to maintain the leading position on the market of health tourism services, it is necessary to raise the standard of health services, carry out further investments in modern health resort infrastructure that is open to innovative and unconventional solutions combining traditional and modern methods of treatment as well as preventive healthcare and leisure. There is a need to constantly adapt the health tourism product to the changing needs of patients and to create new brand of products as well as acquire new groups of recipients who finance their stay in health establishments.
\end{abstract}

Key worlls health tourism, health resort treatment, health resort brand

\section{Introduction}

From the end of the $20^{\text {th }}$ century, health resort treatment began to experience a kind of renaissance, constituting an important element of the Polish health care system. The main function of health resorts is to improve patients' health as well as provide preventive healthcare and health education (Dryglas, 2006). An aging population, an increase in the amount of free time and income, as well as a healthy lifestyle trend are the main factors for the development of health tourism (Makała, 2016). Health resorts are a kind of health sanctuaries that give the opportunity to move to another environment that enables many stimuli beneficial to the body (Meyer, Bordun, 2013). Health tourism is based on health resort treatment provided by qualified medical staff in health establishments using the healing properties of natural resources, mineral water and climate. Their existence is one of the premises for 
granting a particular area the status of a health resort. The most important methods used in health resort treatment are: balneotherapy with peloid therapy and climatotherapy. The specialization of health resorts depends primarily on their availability.

In Poland, the majority of health resorts are located in the mountains and by the sea. In their immediate surroundings there are areas with high natural and geographical values. Many of them are adjacent to national and landscape parks. Thanks to this location, they display not only medicinal properties, but also recreational and tourist values (Gotowt-Jeziorska, Wyrzykowski, 2005).

Almost half of Polish health resorts are located in two voivodeships: Dolnośląskie (11 resorts) and Małopolskie (9 resorts). West Pomeranian voivodeship ranks $3^{\text {rd }}$ in Poland in terms of the number of health resorts (5). However, in terms of the number of patients visiting Polish resorts, West Pomeranian voivodeship is the undisputed leader. In 2017 , over $25 \%$ of patients (184.8 thousand people) underwent medical treatment in health resorts in West Pomeranian voivodeship. The well-developed tourist accommodation establishment base offering 10,412 beds allowed the reception of such a large number of patients ( $23.47 \%$ on the scale of national health resort treatment) (GUS, 2018).

The aim of the study was to analyze the potential of health resorts in West Pomeranian voivodeship and to assess the development of tourist traffic in health resorts in recent years.

\section{Basics of health resorts in West Pomeranian voivodeship}

The coastal location of West Pomeranian voivodeship and the presence of rich peloid deposits and healing waters have contributed to the creation and development of attractive climate, peat and mineral health resorts. Even before the war, resorts such as Kołobrzeg (Kolberg), Połczyn Zdrój (Bad Polzin), Świnoujście (Swinemünde) and Międzyzdroje (Misdroy) experienced dynamic development. Health resort activities are carried out in West Pomeranian voivodeship in the area of 5 gminas that currently have the status of a health resort (Kołobrzeg, Połczyn Zdrój, Kamień Pomorski, Świnoujście and Dabki) and through individual centers in other coastal towns, e.g. in Rewal gmina (Pobierowo, Pogorzelica and Niechorze) (Urząd Marszałkowski, 2013).

The health resort tradition of Świnoujście dates back to 1822, when patients went there mainly to try the then fashionable sea bathing. After the discovery of brine springs in 1897, Świnoujście gained popularity and over time developed into one of the most attractive health resorts with the best offer in Europe (Urząd Marszałkowski, 2013). Before the Second World War, Świnoujście was one of the largest German resorts.

The Kamien Pomorski Health Resort was established as a result of the discovery of a nearby brine deposit in 1876. The later discovered peloid deposits, an attractive geographical location and a unique microclimate resulted in the city quickly taking on the character of a health and recreation center. Although in the interwar period it was a small health resort, its greatest development occurred after the Second World War.

Kołobrzeg is one of the oldest cities in Pomorze. The greatest development of the city occurred after 1872, when the city lost its fortress status and transformed into a resort. It is the largest Polish health resort. It can accommodate over 7,000 patients and holiday-makers at one time. In the city and its surroundings there are sources of mineral water, as well as brine and peat deposits. An additional advantage is the well-developed transport network (Kubicki, Kulbaczewska, 2013). Kołobrzeg was the first health resort in Poland with a railway connection, which was established in 1859. 
Połczyn Zdrój is a resort known in Poland and abroad since the $19^{\text {th }}$ century. Due to rich deposits of excellent quality peat and Permian brine, the city successfully cultivates and develops over 300-year-old health resort traditions, since mineral waters were discovered there as early as 1688 . Połczyn-Zdrój is the only health resort located in Drawskie Lakeland, among moraine hills, lakes and forests, $57 \mathrm{~km}$ from Koszalin and $150 \mathrm{~km}$ from Szczecin. The location of the city in "Połczyn Switzerland" as well as climate and medicinal values contribute to its charm (Urząd Marszałkowski, 2013).

The youngest health resort in West Pomeranian voivodeship - Dąki - is a small town located in Darłowo gmina. It obtained the status of a health resort in 2007. However, the beginnings of the resort date back to the beginning of the $20^{\text {th }}$ century, when the town became a well-known seaside resort. Before the Second World War, a resort that was a part of the Berlin healthcare fund operated there (GUS, 2011). Dabki is a rather unusual seaside resort, as on the one hand, it has a beautiful, sandy beach, and on the other hand, is located next to Bukowo Lake.

Although natural conditions completely determine the location of health resorts, obtaining the status of one is not an arbitrary decision, but one based on legal regulations, which allow the separation of areas called "health resorts" in order to use and protect natural medicinal raw materials that are the basis for conducting health resort treatment (Kasprzak, 2016). The activity of health resorts in Poland is regulated by the Act of July 28, 2005 on Health Resort Medical Care, Health Resorts, Health Resort Protection Areas (Journal of Laws of 2005, No. 167, item 1399), together with its amendment (Act of 4 March 2011 amending the Act on Health Resort Medical Care, Health Resort Protection Areas and Health Resort Gminas and other acts) (Journal of Laws of 2011, No. 73, item 390).

Health resort treatment is mainly carried out by health establishments, which are therapeutic entities that operate in the health resort. Patients can undergo treatment or rehabilitation. The core of health resort treatment is comprehensive therapeutic management, conducted in a different place than the one in which one lives, i.e. in isolation from daily stress and harmful environmental conditions (Ponikowska, 2001). The establishments use the unique natural conditions of the health resort in which they operate. Health establishments include, among others: health resort hospitals, sanatoria, health resort hospitals for children and sanatoria for children, health resort clinics, natural healing centers, hospitals and sanatoria equipped in underground mining excavations (https://www.gov.pl/ web/zdrowie/wykaz-uzdrowisk-wraz-z-kierunkami-leczniczymi).

Therapeutic treatment profiles of health resort are understood as specialization in the treatment of specific disease groups. They are specified for the entire health resort. Moreover, all health establishments located in a given resort are required to carry out therapeutic activity only within the scope of the profiles of a given health resort (Makała, 2016).

The greatest demand for health resort treatment is for rheumatic, orthopedic-traumatic, neurological, heart diseases and diabetes (Ponikowska, 2010). Health resorts in West Pomeranian voivodeship specialize in the following therapeutic profiles:

1. Dabki - orthopedic-traumatic, rheumatic, heart and hypertension, upper and lower respiratory tract, endocrine diseases.

2. Kamień Pomorski - orthopedic-traumatic, neurological, rheumatic, heart and hypertension, lower respiratory tract diseases.

3. Kołobrzeg - orthopedic-traumatic, nervous system, rheumatic, heart and hypertension, lower and upper respiratory tract, endocrine, diabetes, obesity, osteoporosis and skin diseases. 
4. Połczyn Zdrój - orthopedic-traumatic, nervous system, rheumatic, obesity, osteoporosis, women's diseases.

5. Świnoujście - orthopedic -traumatic, nervous system, rheumatic, lower and upper respiratory tract, endocrine, heart, hypertension, obesity, osteoporosis and skin diseases (https://www.gov.pl/web/zdrowie/ wykaz-uzdrowisk-wraz-z-kierunkami-leczniczymi).

\section{Tourist accommodation establishments}

Tourist accommodation establishment is one of the tourism development factors enabling the use of all tourist values, including spa qualities. Its capacity affects the volume of tourist traffic and stimulates its development (Kowalczyk, Derek, 2010).

In 2011, 47 health resorts operated among tourist accommodation establishments in West Pomeranian voivodeship. They accounted for $5.6 \%$ of all accommodation facilities in the voivodeship, while in Poland the share of health establishments in total establishments amounted to $2.2 \%$. For comparison, this percentage was $4.6 \%$ for West Pomeranian voivodeship and 1.6\% for Poland in 2000 (Kubicki, Kulbaczewska, 2013).

In Poland, health resorts are characterized by a diverse ownership structure. Today, the owners of health resorts and health resort hospitals are mostly private persons. There are five health resorts in West Pomeranian voivodeship, including two state-owned companies: Świnoujście Health Resort and Kołobrzeg Health Resort, the privatized health resorts in Połczyn Zdrój and Kamień Pomorski, as well as Dąbki Health Resort, which has never been a state company, and received the status of a health resort in 2007.

There are currently 45 health establishments operating in West Pomeranian voivodeship, which constitute $16 \%$ of all national establishments (Table 1). They have over 10,000 beds from among 44.4 thousand beds in the country, i.e. almost $24 \%$ of national health resort treatment. In 2017 , they serviced 184.8 thousand patients (over $25 \%$ of the number of patients in the country). In comparison to 2010 , the number of beds increased by 0.97 thousand, and by as many as 2.7 thousand in 2000. On the other hand, the number of in-patients increased by 21.7 thousand people as compared to 2010, and as many as 97.81 thousand people when compared to 2000 (Table 2). The largest number of patients was recorded in Kołobrzeg (117 thousand), followed by Świnoujście, Kamień Pomorski and Połczyn Zdrój. When comparing the number of in-patients served by national health establishments in 2000 and 2017, there was an increase of $77 \%$, while West Pomeranian voivodeship recorded an increase by as many as $112 \%$ (GUS, 2011; 2018). Therefore, the region is the undisputed leader of Polish health tourism. Performing approx. 2 million medical services annually, health resorts in the voivodeship handle $90 \%$ of all traffic regarding health resort treatment in Pomorze, and $97 \%$ of foreign patients visiting Pomorze (Strategia rozwoju turystyki w województwie zachodniopomorskim do 2015 roku).

This data confirms the important role of health tourism in the economic development of West Pomeranian voivodeship. 
Tahle 1. List of health establishments in West Pomeranian voivodeship

\begin{tabular}{|c|c|c|c|}
\hline No. & Health resort & Health establishments & Number of beds \\
\hline 1 & 2 & 3 & 4 \\
\hline \multirow{8}{*}{1.} & \multirow{8}{*}{ Dabki } & Health resorts: & \\
\hline & & Sanatorium przemysłu metalowego H. Cegielski & 300 \\
\hline & & Sanatorium Kopalni "Argentyt" & 160 \\
\hline & & Sanatorium "Dukat" & 216 \\
\hline & & Sanatorium "Delfin" & 104 \\
\hline & & Sanatorium "Bursztyn" & 152 \\
\hline & & Sanatorium "Hutmen" & 395 \\
\hline & & Sanatorium "Geovita" & 195 \\
\hline \multirow{8}{*}{2.} & \multirow{8}{*}{ Kamień Pomorski } & \multicolumn{2}{|l|}{ Establishments of Uzdrowisko Kamień Pomorski Sp. z o.o. } \\
\hline & & Health resort hospitals: & \\
\hline & & Szpital Uzdrowiskowy "Mieszko" & 159 \\
\hline & & Health resorts: & \\
\hline & & Sanatorium Uzdrowiskowe "Chrobry" & 139 \\
\hline & & Sanatorium Uzdrowiskowe "Gryf" - subdepartment of "Mieszko" Hospital & 30 \\
\hline & & Natural healing centres: & \\
\hline & & Zakład przyrodoleczniczy "Feniks" & - \\
\hline \multirow{32}{*}{3.} & \multirow{32}{*}{ Kołobrzeg } & Establishments of "Uzdrowisko Kołobrzeg" SA & \\
\hline & & Health resort hospitals: & \\
\hline & & Szpital uzdrowiskowy "Mewa" & 279 \\
\hline & & Szpital uzdrowiskowy "Muszelka" & 160 \\
\hline & & Szpital uzdrowiskowy "Słoneczko" (for children and adolescents) & 246 \\
\hline & & Health resorts: & \\
\hline & & Sanatorium uzdrowiskowe "Kombatant" & 459 \\
\hline & & Health resort clinics: & - \\
\hline & & Health resort clinic in Zakład przyrodoleczniczy nr 1 (Natural healing centre No. 1) & \\
\hline & & Natural healing centers: & \\
\hline & & Zakład przyrodoleczniczy nr 1 & - \\
\hline & & Zakład przyrodoleczniczy nr 2 (located in "Muszelka" health resort hospital) & - \\
\hline & & Establishments of other entities & \\
\hline & & Health resorts: & \\
\hline & & Sanatorium uzdrowiskowe "Willa Fortuna" & 100 \\
\hline & & Sanatorium uzdrowiskowe "MSWiA" & 349 \\
\hline & & Sanatorium uzdrowiskowe „Centrum rehabilitacji Rolników KRUS "NIWA" & 318 \\
\hline & & Sanatorium uzdrowiskowe "Węgiel Brunatny" & 460 \\
\hline & & Sanatorium uzdrowiskowe "Mesko" & 182 \\
\hline & & Sanatorium uzdrowiskowe "San" & 288 \\
\hline & & Sanatorium uzdrowiskowe "Jantar" & 138 \\
\hline & & Sanatorium uzdrowiskowe „Rawar” & 115 \\
\hline & & Sanatorium uzdrowiskowe "Lech" & 164 \\
\hline & & Sanatorium uzdrowiskowe "Koral-Live" & 160 \\
\hline & & Sanatorium uzdrowiskowe "Holtur" & 434 \\
\hline & & Sanatorium uzdrowiskowe "Perełka" & 135 \\
\hline & & Sanatorium uzdrowiskowe "Arka Mega" & 772 \\
\hline & & Sanatorium uzdrowiskowe "Baltyk" & 624 \\
\hline & & Sanatorium uzdrowiskowe "Poznanianka" & 90 \\
\hline & & Sanatorium uzdrowiskowe "Posejdon" & 250 \\
\hline & & Sanatorium uzdrowiskowe "Albax" & 140 \\
\hline & & Sanatorium uzdrowiskowe "Mona Lisa" & 59 \\
\hline
\end{tabular}




\begin{tabular}{|c|c|c|c|}
\hline 1 & 2 & 3 & 4 \\
\hline \multirow{13}{*}{4.} & \multirow{13}{*}{ Połczyn Zdrój } & \multicolumn{2}{|c|}{ Establishments of: "Uzdrowisko Połczyn" SA } \\
\hline & & Health resort hospitals: & \\
\hline & & Szpital uzdrowiskowy "Gryf" & 430 \\
\hline & & Szpital uzdrowiskowy "Podhale" & 135 \\
\hline & & Szpital uzdrowiskowy "Borkowo" & 176 \\
\hline & & Health resorts: & \\
\hline & & Sanatorium uzdrowiskowe "Irena" & 45 \\
\hline & & Health resort clinic & - \\
\hline & & Establishments of other ent & \\
\hline & & Health resorts: & \\
\hline & & Sanatorium uzdrowiskowe "Leo Karli" & 194 \\
\hline & & Sanatorium uzdrowiskowe "Marta" & 100 \\
\hline & & Sanatorium uzdrowiskowe "Hopferówka" & 35 \\
\hline \multirow{20}{*}{5.} & \multirow{20}{*}{ Świnoujście } & \multicolumn{2}{|c|}{ Establishments of "Uzdrowisko Świnoujście" SA } \\
\hline & & Health resort hospitals: & \\
\hline & & Szpital uzdrowiskowy "Światowid" & 79 \\
\hline & & Health resorts: & \\
\hline & & Sanatorium uzdrowiskowe "Henryk" & 50 \\
\hline & & Sanatorium "Admirał I" & 79 \\
\hline & & Sanatorium uzdrowiskowe "Admirał II" & 90 \\
\hline & & Sanatorium uzdrowiskowe "Bursztyn" & 64 \\
\hline & & Sanatorium uzdrowiskowe "Swarozyc" & 31 \\
\hline & & Sanatorium uzdrowiskowe "Tryton" & 100 \\
\hline & & Sanatorium uzdrowiskowe "Trzygłów" & 47 \\
\hline & & Sanatorium uzdrowiskowe "Bałtyk" & 84 \\
\hline & & Sanatorium uzdrowiskowe "Adam i Ewa" & 90 \\
\hline & & Sanatorium uzdrowiskowe "Koral" & 54 \\
\hline & & Sanatorium "Złoty Kłos" & 170 \\
\hline & & Natural healing centers: & \\
\hline & & Zakład Przyrodoleczniczy "Rusałka" with a health resort clinic & - \\
\hline & & Establishments of other ent & \\
\hline & & Sanatorium uzdrowiskowe "Energetyk" & 149 \\
\hline & & Sanatorium uzdrowiskowe "Złoty Kłos" & 170 \\
\hline
\end{tabular}

Source: Ministerstwo Zdrowia (2017).

Table 2. Activities of Health Establishments in West Pomeranian voivodeship and in Poland in the years 2000-2017

\begin{tabular}{llcccc}
\hline \multicolumn{1}{c}{ In years } & $\begin{array}{c}\text { Number of health } \\
\text { establishments }\end{array}$ & $\begin{array}{c}\text { Number of beds } \\
\text { (in thousands) }\end{array}$ & $\begin{array}{c}\text { In-patients } \\
\text { (in thousands) }\end{array}$ & $\begin{array}{c}\text { Out-patients } \\
\text { (in thousands) }\end{array}$ \\
\hline \multirow{2}{*}{2000} & 291 & 34.98 & 412.91 & 73.10 \\
& Poland & 47 & 7.71 & 86.99 & 17.50 \\
\cline { 2 - 6 } 2010 & Zachodniopomorskie voivodeship & 268 & 37.77 & 572.88 & 65.14 \\
& Poland & 50 & 9.44 & 163.10 & 16.97 \\
\hline \multirow{2}{*}{2017} & Pochodniopomorskie voivodeship & 271 & 44.37 & 734.40 & 73.70 \\
& Zachodniopomorskie voivodeship & 45 & 10.41 & 184.80 & 13.30 \\
\hline
\end{tabular}

Source: own elaboration based on GUS $(2011,2018)$. 
In Poland, more than half of in-patients benefited from the stay funded by the National Health Fund, while over $1 / 3$ of patients were self-pay patients (Table 3 ).

Table 3. Structure of in-patients treated in health resort establishments by type of funding stay in 2017

\begin{tabular}{clc}
\hline No. & Financing method for the stay of patients at health resorts & Percent \\
\hline 1. & NFZ & 55.3 \\
2. & Self-pay & 34.7 \\
3. & ZUS & 6.7 \\
4. & PEFRON & 1.5 \\
5. & KRUS & 1.1 \\
6. & Other & 0.7 \\
\hline
\end{tabular}

Source: GUS (2018).

In West Pomeranian voivodeship, the majority of patients also benefit from funding from the National Health Fund. However, it is assuring to see that the number of people who finance their stay in the health resort on their own is growing. Kołobrzeg was the first health resort to receive more self-pay patients (54\%) than those co-financed by the National Health Fund. Foreigners contribute significantly to this (Regionalny Program Operacyjny Województwa Zachodniopomorskiego, 2017). Polish health tourism, especially after joining the European Union, attracts more and more people from abroad (Makała, 2016). Poland occupies a high place in the European ranking in terms of the number of health resorts, which puts it in a good starting position when it comes to the possibility of competing for a foreign client. In this competition, the diversity of individual health resorts, which creates favorable conditions for meeting the needs of various customer groups, is important (Makała, 2016; Krupa, Wołowiec, 2010).

An important advantage of the flourishing health tourism in West Pomeranian voivodeship is its border location, which makes it an attractive place to stay for foreign tourists, in particular Germans, but also Swedes and Danes (Figure 1). The high tourist attractiveness of health resorts in West Pomeranian voivodeship means that health resorts can win in the competitive struggle for not only domestic but also foreign tourists (Januszewska, 2005).

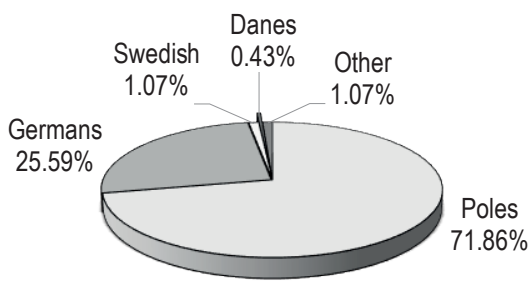

Figure 1. The structure of health resort tourists visiting statutory health resorts in West Pomeranian voivodeship by nationality

In West Pomeranian voivodeship, the years 2000-2004 saw an upward trend in the number of foreign tourists' overnight stays in health establishments. Nationwide trends were similar. The next three years were characterized by stabilization. However, the years 2008-2011 observed a downward trend. Despite this, in 2011, Polish health 
resorts recorded over 63\% more foreign tourists than in 2000. In West Pomeranian voivodeship this increase was almost $74 \%$. In 2011 , over 571,000 stays were granted to foreign tourists in Polish health resorts, of which as many as $87.8 \%$ were organized in West Pomeranian voivodeship. In the years 2000-2011, the dynamics of the number of overnight stays offered to foreign tourists in health establishments was similar to the variable number of foreign tourists in these establishments. In 2011 , as compared to 2000 , the number of overnight stays provided to foreign patients in health resorts increased by $52.2 \%$ in Poland and by $70.1 \%$ in West Pomeranian voivodeship (Kubicki, Kulbaczewska, 2013). In 2016, 93\% of foreigners who used health tourism services in Poland were in health establishments in two voivodeships: West Pomeranian and Dolnośląskie (Ministerstwo Zdrowia, 2017).

\section{Health resort hrand in West Pomeranian voivodeship}

Growing competition on the global health services market and changes in the needs of patients necessitates continuous work on the quality of offered health tourism services. Quality is an inseparable element of a strong brand. Creating the health resort brand is one of the goals of the Self-Government in West Pomeranian voivodeship, which in 2012 became the new owner of Uzdrowisko Świnoujście SA and Uzdrowisko Kołobrzeg SA. In the years 2013-2015, both companies invested almost PLN 40 million in order to improve the quality of health resort services. Several facilities have been modernized and expanded. However, these are not the only elements that comprise the health resort brand. This industry is more and more often expecting brand products. Uzdrowisko Świnoujście SA offers a professional cosmetics line based on natural brine. The set includes creams, gels, bath salt and soaps. A similar series is offered by Uzdrowisko Kołobrzeg SA - under the name "Kołobrzeskie SPA", which proposes products based on peat from the mine belonging to the company (Regionalny Program Operacyjny Województwa Zachodniopomorskiego, 2017).

Połczyn Zdrój Health Resort has also been popularizing its brand product and specializing in the production of cosmetics from the "Połczyńskie Kosmetyki" series, which are based on medical peat and brine water. Body oil, healing soap, bath salt and face mask are an exclusive combination of the unique power of peat and medicinal brine, which can be a substitute for health resort treatments after returning home. Połczyn peat is considered one of the best in Central Europe (http://tfi.kghm.pl/nowa-linia-kosmetykow-z-polczyna).

The health tourism products are now part of the offer of the increasingly competitive health tourism market. This forces entrepreneurs operating in the health resort market to take actions to improve product competitiveness (Hadik, Szromek, Żylak, 2010). The constantly growing number of people traveling for health reasons means that cities with health resorts compete with each other, trying to distinguish and attract as many potential patients as possible. Skillful use of one's own potential and effective presentation of tourist attractions are of key importance in this process (Meyer, Bordun, 2013).

A modern tourist offer based on branded products is a great opportunity for health resorts in West Pomeranian voivodeship. Obtaining the status of a branded product is an indicator of a strong position on the tourist market. Health tourism itself requires constant modification with innovation in the field of health tourism becoming a necessity (Górka, Wartecka-Ważyńska, 2013.

Health tourism is one of the fastest developing forms of tourism. It is one of the prioritized Polish brand products, whose development is of key importance for the regions to achieve competitive advantage, as most often neighboring regions have similar tourist potential, especially in terms of their tourist values. Created tourist products 
are usually similar and directed to the same target group, therefore, brand tourist products become a chance to be distinguished (Meyer, 2013).

\section{Summary}

Two health resort models have been developed on the global health tourism market: resorts that refer to traditional health tourism based mainly on the therapeutic-preventive model, and SPA \& Wellness resorts based on broadly understood recreation and leisure tourism. Polish health treatment with independent medical specialization, balneology and physical medicine is a competitive brand among European Union countries. Current health needs and demographic trends require constant modernization of the system, which aims to ensure comprehensiveness and optimization of treatment and rehabilitation.

West Pomeranian voivodeship, taking advantage of its coastal location with high natural-landscape and health values characterized by the richness of deposits of excellent quality peat and Permian brine and sodiumchloride waters, has become a leader on the market of health tourism services by combining the provision of health treatment services with tourist functions. This position has been maintained and developed for years by investing in modern health resort facilities and creating a competitive global brand. The tourist product, which is based on the therapeutic-prophylactic features offered in health resorts in West Pomeranian voivodeship, is adapted to the needs of modern customers, while maintaining the individuality of the offers of individual health resorts and emphasizing their special features. This is reflected in the steady increase in the number of patients using the services offered by health establishments and in the changing structure of patients in regard to the financing method. The fact that the number of people who finance their stay in a health resort on their own is growing bodes well for the industry. Kołobrzeg was the first health resort in Poland to receive more self-pay patients (54\%) in 2017 than those benefiting from the stay covered by the National Health Fund.

\section{Conclusions}

1. In order to maintain the leading position on the market of health tourism services, it is necessary to raise the standard of health services, carry out further investments in modern health resort infrastructure open to innovative and unconventional solutions that combine traditional and modern methods of treatment as well as preventive health care and leisure.

2. There is a need to constantly adapt the health tourism product to the changing needs of patients and to create new brand products as well as acquire new groups of recipients who finance their stay in health establishments.

\section{References}

Dryglas, D. (2006). Kształtowanie produktu turystycznego uzdrowisk w Polsce. Kraków: Wydawnictwo Uniwersytetu Jagiellońskiego. DzU 2005, nr 167, poz. 1399.

DzU 2011, nr 73, poz. 390.

Gotowt-Jeziorska, A. (ed.), Wyrzykowski J. (2005). Turystyka a uzdrowiska. Warszawa: Polskie Stowarzyszenie Turystyki.

Górka, J., Wartecka-Ważyńska, A. (2013). Stan obecny i możliwości rozwoju turystyki uzdrowiskowej w Polsce. Ekonomiczne Problemy Turystyki, 3 (23), 193-201.

GUS (2018). Działalność lecznicza zakładów lecznictwa uzdrowiskowego i stacjonarnych zakładów rehabilitacji leczniczej w 2017.

GUS (2011). Lecznictwo uzdrowiskowe w Polsce w latach 2000-2010. Kraków. 
Hadik, A., Szromek, A., Żylak, D. (2010). Konkurencyjność produktu turystycznego uzdrowiska Kołobrzeg. Acta Sci. Pol. Oeconomia, $9(4), 153-164$.

http://tfi.kghm.pl/nowa-linia-kosmetykow-z-polczyna (13.05.2019).

http://www2.mz.gov.pl/wwwfiles/ma_struktura/docs/zakladyleczuzdrow201208300926.pdf (13.05.2019).

https://www.gov.pl/web/zdrowie/wykaz-uzdrowisk-wraz-z-kierunkami-leczniczymi (13.05.2019).

Januszewska, M. (2005). Perspektywy rozwoju uzdrowisk w Polsce. Turystyka i Rekreacja, Tom I. Wałbrzych: PWSZ.

Kasprzak, K. (2016). Polskie uzdrowiska jako atrakcja dla turystyki kulturowej. The Central European Journal of Social Sciences and Humanities, 1, 131-156.

Kowalczyk, A., Derek, M. (2010). Zagospodarowanie turystyczne. Warszawa: Wydawnictwo Naukowe PWN.

Krupa, J., Wołowiec, T. (2010). Uzdrowiska Polski Wschodniej wobec wyzwań rozwojowych - turystyka zrównoważona. In: J. Hermaniuk, J. Krupa (eds), Współczesne trendy funkcjonowania uzdrowisk - klastering. Rzeszów: Instytut Gospodarki Wyższej Szkoły Informatyki i Zarządzania.

Kubicki, R., Kulbaczewska, M. (2013). Turystyka uzdrowiskowa w województwie zachodniopomorskim na tle Polski. Ekonomiczne Problemy Turystyki, 3 (23), 239-250.

Makała, H. (2016). Turystyka uzdrowiskowa w Polsce. The Central European Journal of Social Sciences and Humanities, 2 (18), $119-130$.

Meyer, B., Bordun, M. (2013). Fundacja Kołobrzeg Polskie Centrum SPA jako przykład współpracy podmiotów na rzecz rozwoju turystyki uzdrowiskowej. Ekonomiczne Problemy Turystyki, 3 (23), 123-136.

Meyer, B. (2013). Znaczenie RPO w procesie kreowania markowych produktów turystycznych w województwie zachodniopomorskim. The Central European Journal of Social Sciences and Humanities, 2 (12), 65-74.

Ministerstwo Zdrowia (2017). Raport końcowy Zespołu do spraw opracowania koncepcji zmian w zakresie systemu lecznictwa uzdrowiskowego. Retrieved from: http://www2.mz.gov.pl/wwwfiles/ma_struktura/docs/Zakladyleczuzdrow_201208300926.pdf (13.05.2019).

Ponikowska, I. (2010). Kompendium balneologii. Kierunki i wskazania do leczenia uzdrowiskowego. Toruń: Wydawnictwo Adam Marszałek.

Ponikowska, I. (2001). Podstawy kliniczne balneologii i medycyny fizykalnej. Służba Zdrowia, 63-66, 3058-3061.

Regionalny Program Operacyjny Województwa Zachodniopomorskiego (2017). Biuletyn Informacyjny, 3 (29).

Strategia rozwoju turystyki w województwie zachodniopomorskim do 2015 roku (2005/2006). Warszawa-Szczecin-Koszalin: Zachodniopomorska Regionalna Organizacja Turystyczna. Update: December 2008/August 2010.

Urząd Marszałkowski (2013). Audyt Turystyczny Województwa Zachodniopomorskiego.

Cite this article aS: Sieńko-Awierianów, E. (2020). Development of Health Tourism in West Pomeranian Voivodeship. Central European Journal of Sport Sciences and Medicine, 2 (30), 47-56. DOI: 10.18276/cej.2020.2-05. 